\title{
Novel genetic cause of idiopathic short stature
}

\author{
Min Jae Kang, MD, PhD \\ Department of Pediatrics, Hallym \\ University Sacred Heart Hospital, \\ Hallym University College of \\ Medicine, Anyang, Korea
}

Traditionally, the growth hormone - insulin-like growth factor I (GH - IGF-I) axis is the most important signaling pathway in linear growth, and defects in this axis present as growth hormone deficiencies or IGF-I deficiencies. However, subtle changes in serum levels of GH or IGF-I, caused by gene mutations involved in the GH - IGF-I axis, can present as idiopathic short stature (ISS). This paper briefly discusses GHR and IGFALS. In addition, recent studies have shown that many factors, including paracrine signals, extracellular matrix, and intracellular mechanisms of chondrocytes, regulate the growth plate independent of the GH - IGF-I system. Rapid development of diagnostic technologies has enabled discovery of many genetic causes of ISS. This paper discusses 5 genes, SHOX, NPR2, NPPC, FGFR3, and $A C A N$, that may lead to better understanding of ISS.

Keywords: Idiopathic short stature, Growth plate, Gene sequencing

\section{Introduction}

When a child is very short, meaning that his or her height $z$-score is below -2.0, routine laboratory examinations are performed to identify chromosomal aberrations, growth hormone $(\mathrm{GH})$ secretion disorders, or other hormonal or nutritional abnormalities. If these tests identify no reasons and the child had normal birth weight and height, the child is defined as having idiopathic short stature (ISS). Therefore, ISS is a diagnosis of exclusion and includes a diverse group of short stature. ISS also includes normal variants of short stature, such as familial short stature and constitutional delay of growth. These inclusions cause confusion in recognizing ISS as a disorder. There have been many attempts to classify ISS clinically; including familial or nonfamilial; bone age delay or not; pubertal delay or not. However, following the flow of GH secretion, GH action, production of insulin-like growth factor I (IGF-I), and IGF-I action, makes it easier to understand this complex disease ${ }^{1)}$. Recently many genetic causes of ISS have been discovered because diagnostic technologies have developed rapidly, particularly those involving single nucleotide polymorphism array, array-comparative genomic hybridization, whole exome sequencing, genome-wide association studies, whole genome sequencing, RNA sequencing, and methylation assays. This review discusses recent studies centering on novel genetic causes of ISS that may provide better understanding of ISS.

\section{Genetic causes of ISS}

\section{Traditional aspects of genetic causes in the GH - IGF-I axis}

The GH - IGF-I axis is the most important signaling pathway in linear growth, and defects in this axis traditionally present as GH deficiencies or IGF-I deficiencies ${ }^{1)}$. However, some gene mutations involved in the GH - IGF-I axis may cause subtle changes of GH or IGF-I concentrations within the normal range $e^{2,3)}$.

\section{Min Jae Kang, MD, PhD}

Department of Pediatrics, Hallym University Sacred Heart Hospital, 22 Gwanpyeong-ro 170beon-gil, Dongan-gu, Anyang 14068, Korea

Tel: +82-31-380-3730

Fax: +82-31-380-1900

E-mail: mjkang@hallym.or.kr https://orcid.org/0000-0003-30800941
ISSN: 2287-1012(Print)

ISSN: 2287-1292(Online) 


\section{1) $G H R$}

The inactivating mutation of the GH receptor $(G H R)$ gene, which causes complete insensitivity to GH and a very low IGF-I level, presents as Laron dwarfism ${ }^{4)}$. However, there is an area of overlap between ISS and GH insensitivity ${ }^{1)}$, which means that a mild defect of the GHR gene may cause ISS that presents as a lower serum IGF-I concentration, and a higher mean 12hour serum GH concentration ${ }^{5)}$. In such ISS children, serum concentrations of GH binding protein, which is identical to the extracellular domain of the GHR, are low $^{6-8)}$, suggesting that these children may have abnormalities in the GHR gene. Goddard et al. ${ }^{9)}$ found a heterozygous mutation in the extracellular domain of the GHR gene in 4 of 14 ISS children with low levels of $\mathrm{GH}$ binding protein. Children with this $G H R$ gene mutation had marginal growth responses to exogenous $\mathrm{GH}$ treatment, suggesting partial insensitivity to $\mathrm{GH}$.

\section{2) IGFALS}

Growth failure can be caused not only by an absolute defect of the IGF-I, but also by a defect of the bioavailable IGF-I. Under normal conditions, about $80 \%$ of circulating IGF-I is in the form of ternary complex, which is composed of IGF-I, IGF binding protein-3 (IGFBP-3), and acid-labile subunit (ALS) ${ }^{10)}$. This complex plays an important role in regulating the bioavailability of IGF-I by prolonging its half-life ${ }^{11,12}$. Family studies of patients who have homozygous $A L S$ gene mutations have shown that heterozygosity for an $A L S$ defect may decrease stature and head circumference compared with those of noncarriers ${ }^{11,12)}$. Therefore, ALS abnormalities should be considered when circulating levels of IGF-I and IGFBP-3 are lower than those in the normal population.

\section{Novel insights of genetic causes beyond the GH - IGF-I axis}

Normal growth in children requires not only a normal GH - IGF-I axis but also normal local signals and environments within the epiphyseal growth plate. Recent studies have shown that many factors independent of the GH - IGF-I system regulate this growth plate, including paracrine signals, extracellular matrix, and intracellular mechanisms of chondrocytes $^{13-15)}$. Phenotypic spectrums of these related genes exist. If homozygous mutations disrupt the functions of critical genes, patients usually present with skeletal dysplasia, enabling clinicians to recognize the disease easily. However, if the genes are less critical and their functions are impaired by heterozygous mutations, patients may present with ISS without syndromic features $^{13)}$. The initial approach to these candidate genes was to compare data between carriers and noncarriers among the patient's relatives. The following subsections summarize five genes, SHOX, NPR2, NPPC, FGFR3, and ACAN, found in ISS children.

\section{1) $S H O X$}

Short stature homeobox-containing gene, or SHOX, is located at pseudoautosomal region 1 (PAR1) of Xp22.33 and Yp11.2 $2^{16-}$ ${ }^{18)}$. SHOX protein is a transcriptional factor for chondrocyte differentiation. SHOX mutation causes a broad phenotypic spectrum with an apparent gene-dose effect ${ }^{14)}$. A homozygous mutation causes Langer mesomelic dysplasia (MIM\# 249700), which presents as severe skeletal dysplasia, severely short stature, extreme shortening of the long bones in the arms and legs (mesomelia), and Madelung deformity ${ }^{19)}$. A heterozygous mutation causes Léri-Weill dyschondrosteosis (MIM\# 127300) with milder skeletal dysplasia ${ }^{20)}$. In Turner syndrome (MIM\# 313000), skeletal dysplasia of Léri-Weill dyschondrosteosis phenotype presents when the defect in the X chromosome involves PAR $1^{21)}$. A heterozygous aberration of the SHOX gene is responsible for $2 \%-15 \%$ (mean $3.8 \%$ ) of ISS, depending on the study ${ }^{20,22,23)}$. ISS children with SHOX protein insufficiency may have body proportions that are either mildly affected or within the normal range $e^{24)}$. In addition, a heterozygous deletion of the downstream or upstream enhancer of the SHOX gene causes a phenotype similar to that caused by a defect of the SHOX gene itself $^{23,25)}$.

\section{2) NPR2}

The NPR2 gene is located at $9 \mathrm{p} 13$ and encodes natriuretic peptide receptor $B$ (NPR-B), which has high affinity for c-type natriuretic peptide $(\mathrm{CNP})$, an important paracrine factor that acts as a positive regulator in the growth plate. When CNP binds to NPR-B, dimerization of the NPR-B activates the guanylyl cyclase in the cytosolic domain ${ }^{26)}$, and then, cGMP activates the type II cGMP-dependent protein kinase ${ }^{27)}$. This activation inhibits the MAPK pathway, which antagonizes the fibroblast growth factor receptor 3 (FGFR3) signaling. Therefore, CNP NPR-B signaling increases the proliferation and differentiation of chondrocytes ${ }^{28)}$. A homozygous mutation causes acromesomelic dysplasia, Maroteaux type (MIM\# 602875) which is characterized by extremely short stature, short limbs, a severe skeletal dysplasia ${ }^{29)}$. A heterozygous mutation causes a phenotype similar to that caused by SHOX haploinsufficiency with mesomelia, except for the absence of Madelung deformity $^{30)}$. Recent studies have suggested that $2 \%-3 \%$ of ISS cases have a heterozygous loss-of-function mutation of the NPR2 gene ${ }^{31-33)}$, either with or without abnormal body proportions. Wang et $\mathrm{al}^{33)}$ reported a prevalence of $13.6 \%$ in familial cases, suggesting that such variants frequently explain patients with nonsyndromic familial ISS.

\section{3) $N P P C$}

The NPPC gene is located at $2 \mathrm{q} 37$ and encodes CNP, which is a ligand for NPR-B, as described above. NPR2 variants have been widely reported in ISS children, but to date no NPPC mutation has been reported in human. Recently, Hisado-Oliva et al. ${ }^{34)}$ identified 2 heterozygous NPPC mutations in 2 families with proportionate short stature and small hands, which was the first report. This finding strengthens the evidence for clinical trials of CNP analog treatment in short stature. 


\section{4) FGFR3}

The FGFR3 gene is located at 4p16.3, and paracrine signaling of FGF - FGFR3 is well known as a negative regulator of growth plate chondrogenesis ${ }^{35)}$. Its gain of function mutation affects the growth plate through various cellular processes, including decreasing proliferation in the proliferative zone, accelerating the onset of hypertrophic differentiation, decreasing the size of the hypertrophic chondrocytes, and decreasing matrix production $^{35}$. Therefore, activating mutation of the FGFR3 gene results in inhibited long bone growth with skeletal dysplasia. The wide range of phenotype includes hypochondroplasia (MIM\# 146000), achondroplasia (MIM\# 100800), thanatophoric dysplasia (MIM\# 187600), and a lethal skeletal dysplasia with very short limbs and underdeveloped ribs ${ }^{36-38)}$. Several studies have failed to find a relationship between FGFR3 and ISS ${ }^{39,40)}$, but one recent report identified an activating mutation of FGFR3 that caused proportionate familial short stature ${ }^{41)}$. Therefore, if short stature is transmitted in an autosomal dominant pattern, FGFR3 should be considered as a cause of ISS.

\section{5) $A C A N$}

Aggrecan is the most abundant proteoglycan of growth plate cartilage and is crucial for their structure and function ${ }^{42)}$. The $A C A N$ gene, which encodes aggrecan, is located at 15q26.1, and its mutation leads to aggrecan deficiency, abnormal structure of the cartilage extracellular matrix, decreasing chondrocyte proliferation, and accelerating hypertrophic chondrocyte differentiation. A homozygous mutation causes spondyloepimetaphyseal dysplasia aggrecan type (MIM\# 612813), which presents as severe skeletal dysplasia, extremely short stature, brachydactyly, and severe midface hypoplasia ${ }^{43}$. A heterozygous mutation causes milder skeletal dysplasia, associated with adult height $z$-scores of -2.0 to -4.0 , which is called spondyloepiphyseal dysplasia Kimberley type (MIM\# $608361)^{44)}$. As aggrecan is important to the articular cartilage, osteochondritis dissecans (MIM\# 165800) and early-onset osteoarthritis occurs. A heterozygous mutation of ACAN was found in ISS children who have no evident radiographic skeletal dysplasia ${ }^{45-47)}$. Their statures were disproportionate or proportionate, and some of them had advanced bone age, which

\section{Table 1. Summary of genetic causes of idiopathic short stature}

\begin{tabular}{lll}
\hline Gene & \multicolumn{1}{c}{ Mechanism } & Effect on protein \\
\hline In the GH - IGF-I axis & GH signaling & Loss of function \\
GHR & IGF-I signaling & Loss of function \\
IGFALS & & \\
$\begin{array}{l}\text { Outside the GH - IGF-I axis } \\
\text { SHOX }\end{array}$ & $\begin{array}{l}\text { Intracellular } \\
\text { transcription factor }\end{array}$ & Loss of function \\
NPR2 & Paracrine signal & Loss of function \\
NCCP & Paracrine signal & Loss of function \\
FGFR3 & Paracrine signal & Gain of function \\
ACAN & Cartilage extracellular & Abnormal structure \\
& matrix & \\
\hline
\end{tabular}

led to early cessation of growth ${ }^{47)}$. A case of ISS with novel heterozygous mutation with early-onset multiple disc herniation has also been reported ${ }^{45)}$. Compared to the prevalences of SHOX and NPR2, the prevalence of gene variants of ACAN is not widely known, however, Hu et al. ${ }^{48)}$ reported $1.4 \%$ of nonsyndromic short stature patients and $2.5 \%$ of familial short stature patients.

\section{Conclusions}

Recent diagnostic technologies for gene hunting have enabled finding more causative genes associated with short stature. This paper discussed two genes involved in the GH - IGF-I axis and five genes beyond the GH - IGF-I axis. This paper discussed two genes involved in the GH - IGF-I axis and five genes beyond the GH - IGF-I axis (Table 1). Subtle changes in serum levels of GH binding protein, IGF-I, and IGFBP-3 may provide information to enable better approaches to screening genes associated with the GH - IGF-I axis. In addition, mild but specific phenotypes, including those involving body proportion or skeletal dysplasia features, may provide many clues that will aid in accessing involved genes within the growth plate. There are many candidate genes, and screening for all of them would require prohibitive investments of time and money. Therefore, more specific clues are needed about which genes to target.

\section{Conflict of interest}

No potential conflict of interest relevant to this article was reported.

\section{References}

1. Cohen P. Controversy in clinical endocrinology: problems with reclassification of insulin-like growth factor I production and action disorders. J Clin Endocrinol Metab 2006;91:4235-6.

2. Codner E, Mericq MV, Maheshwari HG, Iñguez G, Capurro MT, Salazar T, et al. Relationship between serum growth hormone binding protein levels and height in young men. J Pediatr Endocrinol Metab 2000;13:887-92.

3. Gill MS, Thalange NK, Foster PJ, Tillmann V, Price DA, Diggle PJ, et al. Regular fluctuations in growth hormone (GH) release determine normal human growth. Growth Horm IGF Res 1999;9:114-22.

4. Rosenfeld RG, Rosenbloom AL, Guevara-Aguirre J. Growth hormone $(\mathrm{GH})$ insensitivity due to primary $\mathrm{GH}$ receptor deficiency. Endocr Rev 1994;15:369-90.

5. Attie KM, Carlsson LM, Rundle AC, Sherman BM. Evidence for partial growth hormone insensitivity among patients with idiopathic short stature. The National Cooperative Growth Study. J Pediatr 1995;127:244-50.

6. Carlsson LM, Rowland AM, Clark RG, Gesundheit N, Wong WL. Ligand-mediated immunofunctional assay for 
quantitation of growth hormone-binding protein in human blood. J Clin Endocrinol Metab 1991;73:1216-23.

7. Carlsson LM, Attie KM, Compton PG, Vitangcol RV, Merimee TJ. Reduced concentration of serum growth hormone-binding protein in children with idiopathic short stature. National Cooperative Growth Study. J Clin Endocrinol Metab 1994;78:1325-30.

8. Mauras N, Carlsson LM, Murphy S, Merimee TJ. Growth hormone-binding protein levels: studies of children with short stature. Metabolism 1994;43:357-9.

9. Goddard AD, Covello R, Luoh SM, Clackson T, Attie KM, Gesundheit N, et al. Mutations of the growth hormone receptor in children with idiopathic short stature. The Growth Hormone Insensitivity Study Group. N Engl J Med 1995;333:1093-8.

10. Boisclair YR, Rhoads RP, Ueki I, Wang J, Ooi GT. The acidlabile subunit (ALS) of the $150 \mathrm{kDa}$ IGF-binding protein complex: an important but forgotten component of the circulating IGF system. J Endocrinol 2001;170:63-70.

11. Hwa V, Haeusler G, Pratt KL, Little BM, Frisch H, Koller $\mathrm{D}$, et al. Total absence of functional acid labile subunit, resulting in severe insulin-like growth factor deficiency and moderate growth failure. J Clin Endocrinol Metab 2006;91:1826-31.

12. van Duyvenvoorde HA, Kempers MJ, Twickler TB, van Doorn J, Gerver WJ, Noordam C, et al. Homozygous and heterozygous expression of a novel mutation of the acidlabile subunit. Eur J Endocrinol 2008;159:113-20.

13. Baron J, Sävendahl L, De Luca F, Dauber A, Phillip M, Wit JM, et al. Short and tall stature: a new paradigm emerges. Nat Rev Endocrinol 2015;11:735-46.

14. Wit JM, Oostdijk W, Losekoot M, van Duyvenvoorde HA, Ruivenkamp CA, Kant SG. Mechanisms in endocrinology: novel genetic causes of short stature. Eur J Endocrinol 2016;174:R145-73.

15. Andrade AC, Jee YH, Nilsson O. New genetic diagnoses of short stature provide insights into local regulation of childhood growth. Horm Res Paediatr 2017;88:22-37.

16. Ellison JW, Wardak Z, Young MF, Gehron Robey P, LaigWebster M, Chiong W. PHOG, a candidate gene for involvement in the short stature of Turner syndrome. Hum Mol Genet 1997;6:1341-7.

17. Rao E, Weiss B, Fukami M, Rump A, Niesler B, Mertz A, et al. Pseudoautosomal deletions encompassing a novel homeobox gene cause growth failure in idiopathic short stature and Turner syndrome. Nat Genet 1997;16:54-63.

18. Oliveira CS, Alves C. The role of the SHOX gene in the pathophysiology of Turner syndrome. Endocrinol Nutr 2011;58:433-42.

19. Zinn AR, Wei F, Zhang L, Elder FF, Scott CI Jr, Marttila P, et al. Complete SHOX deficiency causes Langer mesomelic dysplasia. Am J Med Genet 2002;110:158-63.

20. Jorge AA, Souza SC, Nishi MY, Billerbeck AE, Libório DC, Kim CA, et al. SHOX mutations in idiopathic short stature and Leri-Weill dyschondrosteosis: frequency and phenotypic variability. Clin Endocrinol (Oxf) 2007;66:1305 .

21. Clement-Jones M, Schiller S, Rao E, Blaschke RJ, Zuniga A, Zeller R, et al. The short stature homeobox gene SHOX is involved in skeletal abnormalities in Turner syndrome. Hum Mol Genet 2000;9:695-702.

22. Binder G. Short stature due to SHOX deficiency: genotype, phenotype, and therapy. Horm Res Paediatr 2011;75:81-9.

23. Shima H, Tanaka T, Kamimaki T, Dateki S, Muroya K, Horikawa R, et al. Systematic molecular analyses of SHOX in Japanese patients with idiopathic short stature and LeriWeill dyschondrosteosis. J Hum Genet 2016;61:585-91.

24. Malaquias AC, Scalco RC, Fontenele EG, Costalonga EF, Baldin AD, Braz AF, et al. The sitting height/height ratio for age in healthy and short individuals and its potential role in selecting short children for SHOX analysis. Horm Res Paediatr 2013;80:449-56.

25. Benito-Sanz S, Aza-Carmona M, Rodríguez-Estevez A, Rica-Etxebarria I, Gracia R, Campos-Barros A, et al. Identification of the first PAR1 deletion encompassing upstream SHOX enhancers in a family with idiopathic short stature. Eur J Hum Genet 2012;20:125-7.

26. Vasques GA, Arnhold IJ, Jorge AA. Role of the natriuretic peptide system in normal growth and growth disorders. Horm Res Paediatr 2014;82:222-9.

27. Krejci P, Masri B, Fontaine V, Mekikian PB, Weis M, Prats $\mathrm{H}$, et al. Interaction of fibroblast growth factor and $\mathrm{C}$-natriuretic peptide signaling in regulation of chondrocyte proliferation and extracellular matrix homeostasis. J Cell Sci 2005;118(Pt 21):5089-100.

28. Olney RC. C-type natriuretic peptide in growth: a new paradigm. Growth Horm IGF Res 2006;16 Suppl A:S6-14.

29. Bartels CF, Bükülmez H, Padayatti P, Rhee DK, van Ravenswaaij-Arts C, Pauli RM, et al. Mutations in the transmembrane natriuretic peptide receptor NPR-B impair skeletal growth and cause acromesomelic dysplasia, type Maroteaux. Am J Hum Genet 2004;75:27-34.

30. Hisado-Oliva A, Garre-Vázquez AI, Santaolalla-Caballero F, Belinchón A, Barreda-Bonis AC, Vasques GA, et al. Heterozygous NPR2 mutations cause disproportionate short stature, similar to Léri-Weill dyschondrosteosis. J Clin Endocrinol Metab 2015;100:E1133-42.

31. Amano N, Mukai T, Ito Y, Narumi S, Tanaka T, Yokoya S, et al. Identification and functional characterization of two novel NPR2 mutations in Japanese patients with short stature. J Clin Endocrinol Metab 2014;99:E713-8.

32. Vasques GA, Amano N, Docko AJ, Funari MF, Quedas EP, Nishi MY, et al. Heterozygous mutations in natriuretic peptide receptor-B (NPR2) gene as a cause of short stature in patients initially classified as idiopathic short stature. J Clin Endocrinol Metab 2013;98:E1636-44.

33. Wang SR, Jacobsen CM, Carmichael H, Edmund AB, Robinson JW, Olney RC, et al. Heterozygous mutations in natriuretic peptide receptor-B (NPR2) gene as a cause of short stature. Hum Mutat 2015;36:474-81. 
34. Hisado-Oliva A, Ruzafa-Martin A, Sentchordi L, Funari MFA, Bezanilla-López C, Alonso-Bernáldez M, et al. Mutations in C-natriuretic peptide (NPPC): a novel cause of autosomal dominant short stature. Genet Med 2017 Jun 29 [Epub]. https://doi.org/10.1038/gim.2017.66.

35. Karuppaiah K, Yu K, Lim J, Chen J, Smith C, Long F, et al. FGF signaling in the osteoprogenitor lineage nonautonomously regulates postnatal chondrocyte proliferation and skeletal growth. Development 2016;143:1811-22.

36. Rousseau F, Bonaventure J, Legeai-Mallet L, Pelet A, Rozet $J M$, Maroteaux P, et al. Mutations in the gene encoding fibroblast growth factor receptor-3 in achondroplasia. Nature 1994;371:252-4.

37. Martínez-Frías ML, de Frutos CA, Bermejo E, Nieto MA; ECEMC Working Group. Review of the recently defined molecular mechanisms underlying thanatophoric dysplasia and their potential therapeutic implications for achondroplasia. Am J Med Genet A 2010;152A:245-55.

38. Bonaventure J, Rousseau F, Legeai-Mallet L, Le Merrer M, Munnich A, Maroteaux P. Common mutations in the gene encoding fibroblast growth factor receptor 3 account for achondroplasia, hypochondroplasia and thanatophoric dysplasia. Acta Paediatr Suppl 1996;417:33-8.

39. Mancilla EE, Poggi H, Repetto G, García C, Foradori A, Cattani A. Mutations in the fibroblast growth factor receptor 3 gene (FGFR3) in Chilean patients with idiopathic short stature, hypochondroplasia and achondroplasia. Rev Med Chil 2003;131:1405-10.

40. Mamada M, Yorifuji T, Kurokawa K, Kawai M, Momoi T, Nakahata T. Prevalence of mutations in the FGFR3 gene in individuals with idiopathic short stature. Clin Pediatr
Endocrinol 2006;15:61-4.

41. Kant SG, Cervenkova I, Balek L, Trantirek L, Santen GW, de Vries MC, et al. A novel variant of FGFR3 causes proportionate short stature. Eur J Endocrinol 2015;172:76370.

42. Roughley PJ, Mort JS. The role of aggrecan in normal and osteoarthritic cartilage. J Exp Orthop 2014;1:8.

43. Tompson SW, Merriman B, Funari VA, Fresquet M, Lachman RS, Rimoin DL, et al. A recessive skeletal dysplasia, SEMD aggrecan type, results from a missense mutation affecting the C-type lectin domain of aggrecan. Am J Hum Genet 2009;84:72-9.

44. Gleghorn L, Ramesar R, Beighton P, Wallis G. A mutation in the variable repeat region of the aggrecan gene (AGC1) causes a form of spondyloepiphyseal dysplasia associated with severe, premature osteoarthritis. Am J Hum Genet 2005;77:484-90.

45. Dateki S, Nakatomi A, Watanabe S, Shimizu H, Inoue $\mathrm{Y}, \mathrm{Baba} \mathrm{H}$, et al. Identification of a novel heterozygous mutation of the Aggrecan gene in a family with idiopathic short stature and multiple intervertebral disc herniation. J Hum Genet 2017;62:717-21.

46. Quintos JB, Guo MH, Dauber A. Idiopathic short stature due to novel heterozygous mutation of the aggrecan gene. J Pediatr Endocrinol Metab 2015;28:927-32.

47. Nilsson O, Guo MH, Dunbar N, Popovic J, Flynn D, Jacobsen C, et al. Short stature, accelerated bone maturation, and early growth cessation due to heterozygous aggrecan mutations. J Clin Endocrinol Metab 2014;99:E1510-8.

48. Hu X, Gui B, Su J, Li H, Li N, Yu T, et al. Novel pathogenic ACAN variants in non-syndromic short stature patients. Clin Chim Acta 2017;469:126-9. 